\title{
Development and Implementation of the Balanced Scorecard for a Higher Educational Institution using Business Intelligence Tools
}

\author{
Alicia Valdez, Griselda Cortes, Sergio Castaneda, Laura \\ Vazquez \\ Research Center \\ Autonomous University of Coahuila \\ Coahuila, Mexico
}

\author{
Jose Medina, Gerardo Haces \\ Research Center \\ Autonomous University of Tamaulipas \\ Tamaulipas, Mexico
}

\begin{abstract}
The objective of designing a strategy for an institution is to create more value and achieve its vision, with clear and coherent strategies, identifying the conditions in which they are currently, the sector in which they work and the different types of competences that generate, as well as the market in general where they perform, to create this type of conditions requires the availability of strategic information to verify the current conditions, to define the strategic line to follow according to internal and external factors, and in this way decide which methods to use to implement the development of a strategy in the organization. This research project was developed in an institution of higher education where the strategic processes were analyzed from different perspectives i.e. financial, customers, internal processes, and training and learning using business intelligence tools, such as Excel Power BI, Power Pivot, Power Query and a relational database for data repository; which helped having agile and effective information for the creation of the balanced scorecard, involving all levels of the organization and academic units; operating key performance indicators (KPI's), for operational and strategic decisions. The results were obtained in form of boards of indicators designed to be visualized in the final view of the software constructed with previously described software tools.
\end{abstract}

Keywords-Business intelligence; balanced scorecard; key performance indicators; BI Tools

\section{INTRODUCTION}

Business intelligence (BI) has had different meanings over the last few years, a pioneer in the creation of the term was Richard Green who in 1996, defined it as "Information processed" cited by [1], for Dresner [2], BI is "a set of concepts and methods to improve the decision-making process, using a fact-based support system." For the Data Warehouse Institute [3] BI is an umbrella term, i.e. the combination of technology, tools and processes that allow the transformation of stored data into information, this information into knowledge and this knowledge apply to a business plan or strategy. In this sense, BI must be part of the business strategy, since it allows the use of optimization of resources, monitoring the fulfillment of the company's objectives and the ability to make good decisions, to obtain better results. BI provides insight and in-depth knowledge of the operation of the organization, through access and analysis of quantitative information sources. Based on the definition of the Data Warehouse Institute, BI is, for the present project, as the group of technologies, techniques, concepts, tools and methods that make it possible to take advantage of historical and current data to support decision making through reports, projections, and predictions. Encouraging, that the data handled contribute to the achievement of the objectives of the institution [4].

Some organizations lack a strategy to create value and achieve their vision with clear and coherent strategies, identifying the conditions in which they are, the sector in which they work and the different types of competencies they generate, as well as the market in general where they work, using the use of computational tools.

To create this kind of conditions requires strategic information to verify the current conditions, to set the strategic line to follow according to internal and external factors, and thus decide what methods to use for implementing the development of a strategy in the organization that allows them to reach the established goals.

The measurement systems have been created and designed with a specific purpose. Used for several decades [5] the Balanced Scorecard (BSC), has a background in the "Tableau de Board", proposed by French engineers in the 70s [6], is a measurement system that aims to visualize the useful information to diagnose the situation and to manage the company [7].

The establishment of a BSC in organizations will constitute a set of established links and shared resources with a common purpose in support of the strategic planning of organizations and increase the competitiveness and productivity [8].

For this research within the methodological framework, the background that gave rise to the problem, where the work method, and the data were collected, the description of the areas involved and the justification of the investigation were reviewed; the purpose of this research is to define key elements for the BSC, such as: To have an organizational framework to specify the structure of the BSC, determine the organization of the project, ensure optimal project management, plan communication and consider critical success factors. 
Within the theoretical framework, it is to define the strategic principles, to verify the previous strategic conditions, to establish the strategic line to follow, and to integrate the $\mathrm{BSC}$ in the development of the strategy; subsequently, define strategic objectives and link them through cause - effect relationships, select key indicators, set target values and determine strategic actions; the methodology is used to perform the implementation management, deploying the BSC at all levels of the company, directing to the selected business units, creating the link between the business units and finally achieving the expected results and the documentation required to document them for proper management.

Speckbacher, Bischof and Pfeiffer found in their large scale research under German companies a high support for ambivalence in the BSC concept [9], they defined three types of BSC: Type 1, a specific multidimensional framework for strategic performance measurement; Type 2, a Type 1 BSC with cause-effect relationships; and Type 3, a combining of Type 2 BSC with objectives, action plans, results, and connecting incentives with BSC.

Other authors describe the conditions an organization must in order to be able to apply the BSC, and suggest that this method is universally applicable [10].

The BSC [11] provides managers with the instrument they need to navigate towards future competitive success. Today organizations are competing in complex environments and therefore it is vital that they have an accurate understanding of their goals and the methods they must use to achieve them. The BSC translates an organization's strategy and mission into a broad set of performance measures that provide the framework for a strategic management and measurement system. The BSC measures the performance of the organization from four balanced perspectives: Financial, customers, internal processes, and training and growth.

"Business Intelligence applications are decision support tools that enable real-time, interactive access, analysis, and manipulation of business-critical information. These applications provide users with a greater understanding that allows them to identify the opportunities and problems of the business. Users are able to access and leverage a vast amount of information and analyze their relationships and understand the trends that are lately supporting business decisions. These tools prevent a potential loss of knowledge within the enterprise resulting from a massive re-build that is not easy to read or use" [12].

The main objective of this research is to develop and manage the implementation of a BSC, which supports strategic decision making at all levels of an organization, using BI software to identify that strategic actions are carried out in accordance with degree of progress of the defined key performance indicators (KPI's), to ensure optimal project management.

Basically, this study has four sections:

In Section I, the fundamental concepts were shown i.e. the introduction. In Section II, the four perspectives are described. Also, the values of the KPI's were also stated. Thus, Section III describes the methodology, and Section IV describes the principal findings of the project.

\section{BALANCED SCORECARD PERSPECTIVES}

The perspectives considered for the project were four:

- Financial perspective: Improvement in income, use of funds and asset management.

- Customer perspective: Students-users.

- Internal processes perspective: Organizational value chain improvement.

- Training and learning perspective: Human capital improvement, organizational information.

Each perspective represents an element in the network of activities and processes of the company, giving a global vision in which the strategy is the center of the management systems. The four perspectives are applicable to many companies and educational institutions, government agencies, and others.

Fig. 1 shows the BSC stages, where the four perspectives are the base for obtain strategic results.

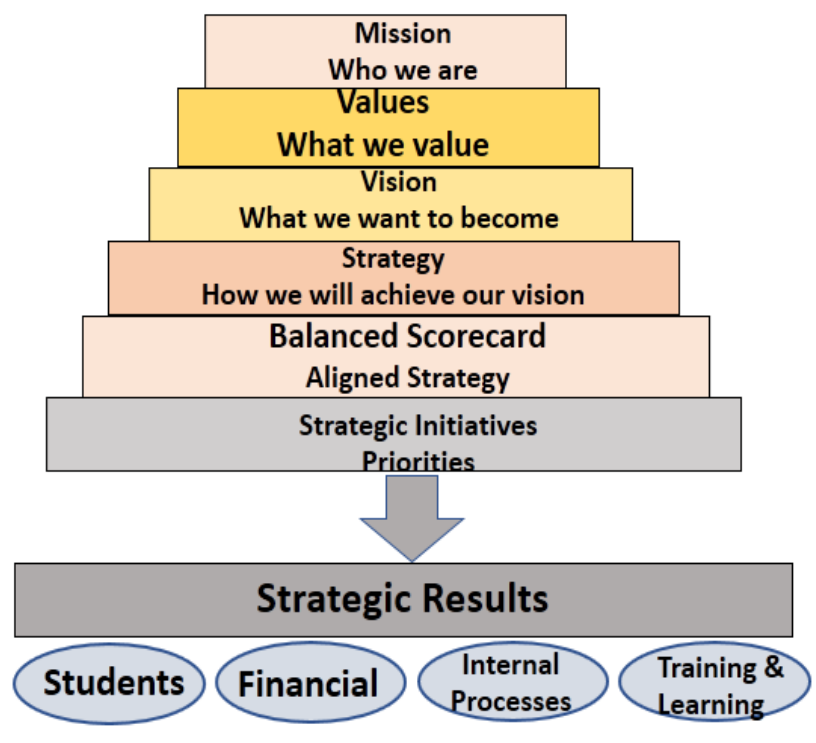

Fig. 1. BSC vision and strategy.

Student's perspective: Every company considers clients as a fundamental element; the company or institution does not exist without clients or in the case of educational institutions students or government departments. Customer satisfaction is intrinsic to business performance, in addition to it depends on economic and financial objectives. However, satisfaction is not always easy to achieve as a basic goal on which others depend. The customer perspective defines the value proposition for the target clients, providing the context for intangible assets to create value. The key questions to answer would be: How is the institution perceived by students about the satisfaction, acquisition, retention and delivery of continuous benefits to the students? What objectives are derived from the characteristics 
of the students that are necessary to reach the value-added proposals?

Financial perspective: This perspective could be considered as the most classic and implemented to a greater or lesser extent in all companies, educational institutions or government agencies to respond if the expected economic and financial results are being achieved by translating the principles of the strategy into values that reflect the situation and economic trend of the company or institution, therefore describes the tangible results of the strategy in financial terms.

Traditionally, a variety of economic and financial indicators are available for solvency, profitability, cost reduction, etc.

It is necessary to consider the opportunity and necessity of each one of these indicators so that they are used in each moment those that are useful, since otherwise it will have a collection of data facilitated by the indicators without real utility. The key questions to be answered would be: How do the authorities see us? How was research expenditures applied to total expenditures? How were administrative and operational expenditures applied per student? What objectives are derived from the financial expectations of the educational authorities?

Two fundamental aspects can be considered. On the one hand the correct adaptation of objectives and indicators to the business unit in question, and on the other hand the life cycle of the product or service in which the organization or company is located.

Since the financial approach is based on a simple premise, you can only generate more money by selling more or by spending less or making efficient use of resources.

Internal processes perspective: As an extension of the previous perspective, the one relative to internal processes arises. In fact, achieving customer satisfaction by delivering a product or service that meets their expectations needs a set of previous elements that constitute a more or less complex process. The key questions to be answered would be: Which core processes in the value chain would be considered? What objectives are derived from the processes developed by the institution and that are necessary to meet the economic objectives and the students?

This process comprises all the transformation operations in the case of the manufacture and configuration of the service in case of provision of the service, as well as supplies, storage, handling, transportation and distribution. Aspects such as technology, innovation and control complete the process. It is not a question of tackling all processes, but of those considered key and of key importance in the framework of the overall strategy.

In the case of education, it is a matter of covering the improvement of the teaching of face-to-face classes, promoting tutorials, encouraging the use of new technologies, increasing the exchange of new knowledge, implementing management by objectives, increasing quality of services, increase the relationship with the business sector, general services such as quality in classrooms, laboratories, parking, sports courts, and others.
The search for more efficient and effective processes leads to the consideration of procedures such as continuous improvement, which allows mechanisms to detect errors and deficiencies, correct them and improve the process. There is a direct relationship between process management and quality management, which is integrated in the BSC. Time, quality and service become key variables.

The processes describe two fundamental concepts of the strategy, on the one hand from which the products are obtained or the services that are delivered to the clients, on the other hand, the improvement of the processes are directly related with the reduction of costs that in turn are linked to productivity.

Internal processes can be grouped into operational management processes, customer management processes, innovation management processes and social processes.

Training and learning perspective: Customers-students satisfaction, improvement of processes and achievement of economic and financial objectives could not be achieved without fundamental elements such as people, information and organization, designing effective organizational structures.

The human factor in organizations becomes a key asset for the deployment and execution of the strategy and the achievement of the objectives. Information systems, their storage, treatment and dissemination are essential for the development of the objectives.

This perspective identifies the intangible assets that are most important for achieving the desired results for the strategy, identifies which jobs (human capital), which systems (information capital) and what climate (organizational capital), are required to support the processes of value creation; these assets must be aligned with critical internal processes.

The questions to be answered would be: What objectives should be established regarding the capabilities and potentials of the institution, to face the current and future challenges, what strategic resources are considered, can be further improved and created value in staff training, how the organizational climate is considered?

It is about evaluating the ability to innovate, improve and learn, learning and growth are the consequence of professionals involved and motivated.

The continuous training gets an increasing adaptation of the employees to their jobs, and therefore, a better performance producing a spiral of learning-growth that culminates with the best fulfillment of the objectives.

Information is the key piece, so that employees, each at their level can make more convenient decisions at any time.

This perspective reflects the knowledge and skills that the company has, both to produce and provide services, to change and learn.

The foundations on which the BSC is based allow us to reach the objectives of the previous perspectives thanks to the so-called strategic capacities of the company. Intangible assets linked to human capital, information and organization. 


\section{METHODOLOGY}

\section{A. Indicators}

For this study, qualitative and quantitative data were collected, for five years (2010-2015), giving a mixed approach to the research, which involves a process of collection, analysis and linkage of the two types of data to answer the problem, as a strategic planning process, starting from perspectives, the integration to the BSC allows objectives and goals in each one of them to be carried out in a more focused and integral way.

The selection and definition of the indicators was very important issues of the project, a range between 20 to 32 indicators were used approximately divided in each one of the perspectives:

- Financial: 7 indicators represent $22 \%$.

- Clients (Students): 10 indicators represent $31 \%$.

- Internal Process: 7 indicators represent $22 \%$.

- Learning and Growth: 8 indicators represent $25 \%$.

Some of the indicators are shown in Tables I to IV.

TABLE I. FINANCIAL PERSPECTIVE INDICATORS

\begin{tabular}{|l|l|l|l|}
\hline KPI & $\begin{array}{l}\text { Indicator } \\
\text { definition }\end{array}$ & $\begin{array}{l}\text { How is it } \\
\text { calculated }\end{array}$ & Goals \\
\hline $\begin{array}{l}\text { Administrative } \\
\text { overhead rate }\end{array}$ & $\begin{array}{l}\text { Efficiency of } \\
\text { administrative } \\
\text { expenditure }\end{array}$ & $\begin{array}{l}\text { Administrative } \\
\text { expenditure/Total } \\
\text { students } * 100\end{array}$ & $\begin{array}{l}\text { Efficient } \\
\text { economy in } \\
\text { administrative } \\
\text { expenditure } \\
\text { per student }\end{array}$ \\
\hline $\begin{array}{l}\text { Operating } \\
\text { expenses index }\end{array}$ & $\begin{array}{l}\text { Efficiency of } \\
\text { operative } \\
\text { expenditure }\end{array}$ & $\begin{array}{l}\text { Operative } \\
\text { expenditure/Total } \\
\text { students } * 100\end{array}$ & $\begin{array}{l}\text { Efficient } \\
\text { economy in } \\
\text { operative } \\
\text { expenditure } \\
\text { per student }\end{array}$ \\
\hline $\begin{array}{l}\text { Revenue index } \\
\text { for space rent }\end{array}$ & $\begin{array}{l}\text { Efficiency of } \\
\text { operative } \\
\text { expenditure }\end{array}$ & $\begin{array}{l}\text { Income for space } \\
\text { rent/Total students } \\
* 100\end{array}$ & $\begin{array}{l}\text { Efficient } \\
\text { economy in } \\
\text { income for } \\
\text { space rent }\end{array}$ \\
\hline
\end{tabular}

TABLE II. STUDENTS PERSPECTIVE INDICATORS

\begin{tabular}{|l|l|l|l|}
\hline KPI & $\begin{array}{l}\text { Indicator } \\
\text { definition }\end{array}$ & $\begin{array}{l}\text { How is it } \\
\text { calculated }\end{array}$ & Goals \\
\hline $\begin{array}{l}\text { New students } \\
\text { index }\end{array}$ & $\begin{array}{l}\text { Increase the } \\
\text { enrollment of new } \\
\text { students }\end{array}$ & $\begin{array}{l}\text { New } \\
\text { students/300*100 }\end{array}$ & $\begin{array}{l}\text { Efficiency in } \\
\text { the number of } \\
\text { new students }\end{array}$ \\
\hline $\begin{array}{l}\text { Re-entry } \\
\text { students } \\
\text { index }\end{array}$ & $\begin{array}{l}\text { Increase the } \\
\text { enrollment of re- } \\
\text { entry students }\end{array}$ & $\begin{array}{l}\text { Re-entry } \\
\text { students/700* } \\
100\end{array}$ & $\begin{array}{l}\text { Efficiency in } \\
\text { the number of } \\
\text { re-entry } \\
\text { students }\end{array}$ \\
\hline $\begin{array}{l}\text { Students } \\
\text { mobility }\end{array}$ & $\begin{array}{l}\text { Increase students } \\
\text { mobility in other } \\
\text { universities }\end{array}$ & $\begin{array}{l}\text { Students in } \\
\text { mobility/Total } \\
\text { students with } \\
\text { possibilities } * 100\end{array}$ & $\begin{array}{l}\text { Mobility } \\
\text { efficiency }\end{array}$ \\
\hline
\end{tabular}

In Table I, three indicators as administrative overhead rate, operating expenses index and revenue index for space rent are shown with its definition, and goal; the responsible is the administrative secretary, and frequency of the measure for the indicator is monthly.

In Table II, the three indicators presented corresponding to the students' perspective, in this case the new students index, the re-entry students index, and the students mobility; this perspective has other indicators as tutoring, fellowships, internships and level of satisfaction of the student regarding student services.

In Table III, the academic program index and the academic agreements index are shown, these indicators corresponding to internal processes that are related with the academic programs quality.

As the objectives respond to a given strategy, the indicators also, so that for each perspective and for each strategy, concrete objectives and values to be reached are quantified through specific indicators. There are two types of indicators:

1) Inductors: Measure the actions they take to achieve the goal.

2) Result: Measure the degree of obtaining the results.

As a general criterion, no more than two indicators should be established for each objective, the most common being an indicator per objective.

TABLE III. INTERNAL PROCESSES PERSPECTIVE INDICATORS

\begin{tabular}{|l|l|l|l|}
\hline KPI & $\begin{array}{l}\text { Indicator } \\
\text { definition }\end{array}$ & $\begin{array}{l}\text { How is it } \\
\text { calculated }\end{array}$ & Goals \\
\hline $\begin{array}{l}\text { Academic } \\
\text { program index }\end{array}$ & $\begin{array}{l}\text { Strengthen the } \\
\text { academic } \\
\text { programs }\end{array}$ & $\begin{array}{l}\text { Quality } \\
\text { careers/total } \\
\text { careers } * 100\end{array}$ & $\begin{array}{l}\text { Quality } \\
\text { careers. }\end{array}$ \\
\hline $\begin{array}{l}\text { Academic } \\
\text { agreements } \\
\text { index }\end{array}$ & $\begin{array}{l}\text { Increase the } \\
\text { academic } \\
\text { agreements }\end{array}$ & $\begin{array}{l}\text { Academic } \\
\text { agreement/ } \\
\text { proposed } \\
\text { agreements } * 100\end{array}$ & $\begin{array}{l}\text { Efficiency in } \\
\text { the number of } \\
\text { academic } \\
\text { agreements }\end{array}$ \\
\hline
\end{tabular}

TABLE IV. TRAINING AND LEARNING PERSPECTIVE INDICATORS

\begin{tabular}{|l|l|l|l|}
\hline KPI & $\begin{array}{l}\text { Indicator } \\
\text { definition }\end{array}$ & How is it calculated & Goals \\
\hline $\begin{array}{l}\text { Research } \\
\text { projects index }\end{array}$ & $\begin{array}{l}\text { Proposed and } \\
\text { approved } \\
\text { research } \\
\text { projects }\end{array}$ & $\begin{array}{l}\text { Proposed research } \\
\text { projects/Approved } \\
\text { projects } * 100\end{array}$ & $\begin{array}{l}\text { Research } \\
\text { efficiency }\end{array}$ \\
\hline $\begin{array}{l}\text { Index of } \\
\text { teachers with } \\
\text { doctorate } \\
\text { degree }\end{array}$ & $\begin{array}{l}\text { Teachers with } \\
\text { doctorate } \\
\text { degree }\end{array}$ & $\begin{array}{l}\text { Teachers with } \\
\text { doctorate/total } \\
\text { teachers } * 100\end{array}$ & $\begin{array}{l}\text { Efficiency in } \\
\text { the number of } \\
\text { teachers with } \\
\text { doctorate } \\
\text { degree }\end{array}$ \\
\hline
\end{tabular}




\section{B. BSC Construction}

The proposed methodology consists of four phases, shown in Fig. 2.

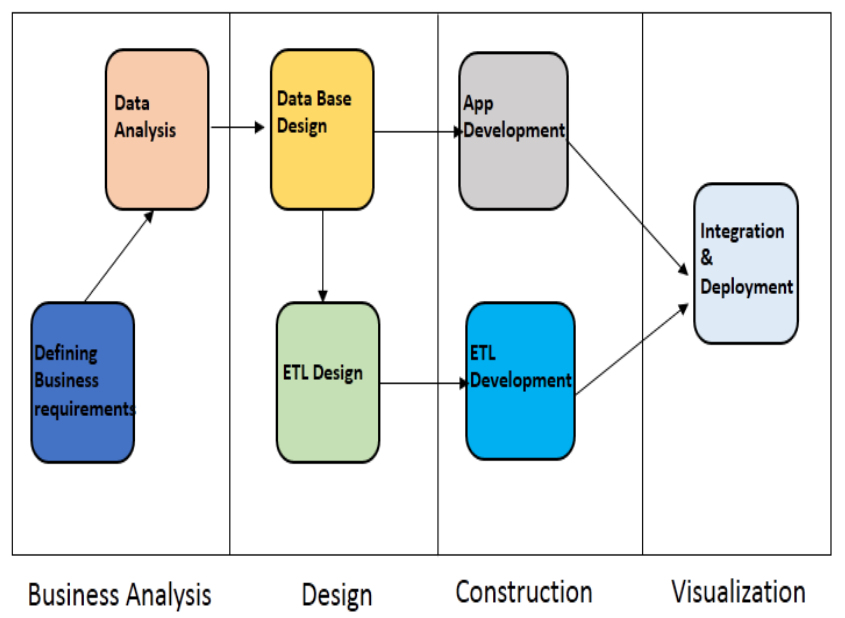

Fig. 2. Methodology phases.

\section{1) Business Analysis Phase}

This phase defines the needs of the institution for the collection and measurement of indicators from the four perspectives: finance, customers, internal processes and training and growth. The policies and procedures of the key processes of the institution are also analyzed.

\section{2) Design Phase}

With the data collected, the database was designed in the SQL Server 2012 relational software shown in Fig. 3; the tools that will be used for the activities of the design to extract, transform and load (ETL) in this process were selected, formatted and presented to display in the selected software. For basic and advanced analysis, we used SQL Server 2012 with Excel, Power Query [13], Power View and Power Pivot [14]. Fig. 3 shows the design of the data diagram for the application that will serve for the storage of the obtained data and later analysis.

\section{3) Construction Phase}

In this phase were built the programs used for the analysis of the data and its subsequent loading and deployment activities. Also in this phase the communication of data between Excel and BI tools was established with queries and reports of large volumes of tabular data.

\section{4) Visualization Phase}

Indicators panels were designed to be visualized in the final view of the software. The analysis of mission-critical data is visualized, in addition to the fundamental needs of the data used, with an information screen viewer and interactive links to the details of key performance indicators (KPI's), following the company model.

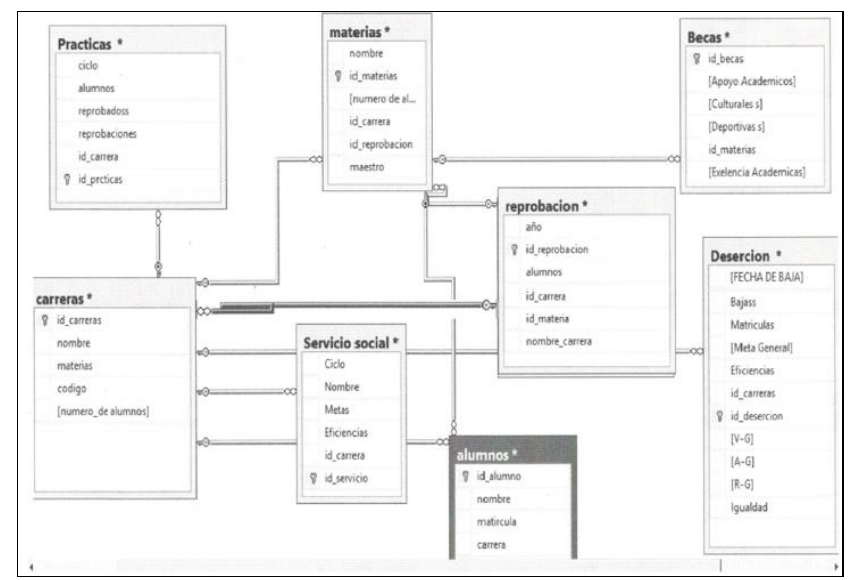

Fig. 3. Database design.

Also were created line graphs, highlights trends, bar graphs, standing out categorical comparisons within a dimension and nominal comparisons through the data.

Once the mission, the vision, the business strategy, and the strategic objectives were defined, the next step was selected the corresponding financial and non-financial indicators, as well as their predicted values. These strategic objectives must be concretized in strategic actions that ensure their achievement; each strategic action was assigned a responsibility, a deadline and a budget. At this step from vision to strategic definition and its achievement in actions, Kaplan and Norton [11] called it "Transforming strategy into action".

Strategic objectives, indicators, values and strategic actions were interrelated through cause-effect relationships. One of the fundamental characteristics of the $\mathrm{BSC}$ is the combination of financial and non-financial indicators, however it is not the most relevant, and since previously organizations have developed dashboards that combine indicators, financial and non-financial.

Kaplan and Norton [11] indicate that management processes and programs were built around structures. Traditional management systems have been built around a financial structure.

\section{BI Tools used}

\section{1) Excel power BI}

This function is used to connect data from a wide range of sources, such as tables of public websites, corporate data in databases, cloud-based sources such as Azure, unstructured data, to display as tables within a spreadsheet.

\section{2) Power pivot}

This tool allows to handle different types of data sources, with large volumes of data, handle multiple selection of data under the concept of data segmentation; automatically groups dates by years, quarters and months, expands and contracts dynamic data, Excel and Power Pivot, allow you to create a data model, as well as a set of tables with relationships. 


\section{3) Power query}

Tool with data search functions, transformations and cleaning of them for exploitation in Excel (formerly known as "Data Explorer"). Power Query enhances Excel's BI with an intuitive and consistent experience to discover, combine and refine data in a wide variety of sources such as relational, structured and semi-structured, OData, Web, Hadoop, Azure, Marketplace and much more, plus Power Query also gives you the ability to search for public data.

Other software was used for the realization of this project, but these tools were the main ones.

\section{RESULTS}

For this case, we analyzed the exposed situation of the Autonomous University of Coahuila, focused mainly on the situation presented in the Faculty of Mechanical and Electrical Engineering, supported by documentation provided, its strategic reflection is complemented by a SWOT analysis.

The BSC core is the strategic map which, when used, helps us to be sure that our strategy is clear enough and can be operational by converting big ideas and visions into a structured, operative and actionable strategy that clearly points out each of the company's units bring differential and balanced value to the achievement of the organization's strategy.

For the case of the central region of the state, the enrollment behavior at this level is 14,516 students graduated from the school year 2014 to 2015 , if we consider the increment factor of 1.49 per year, the enrollment for 2015-2016 would be in an increase to 16,678 students graduated from the upper middle level of the central region of the state of Coahuila, which represents a fairly acceptable level of graduates of upper middle level.

Fig. 4 displays the absorption rate of the Faculty of Mechanical and Electrical Engineering according to the 16,678 graduates of upper secondary level is $1.17 \%$, which represents 196 new students, who were accepted in the school year 20152016; it should be noted that the capacity of absorption can be up to 405 students, product of the capacity in classrooms and spaces that we count, since in the case of the year 2011-2012 a total of 304 students of new entrance were accepted, according to the analysis realized and the goal, which we are proposing based on the analysis of the last 5 years and that we define in this section, we exceed the calculated goal of 298 students of new income.

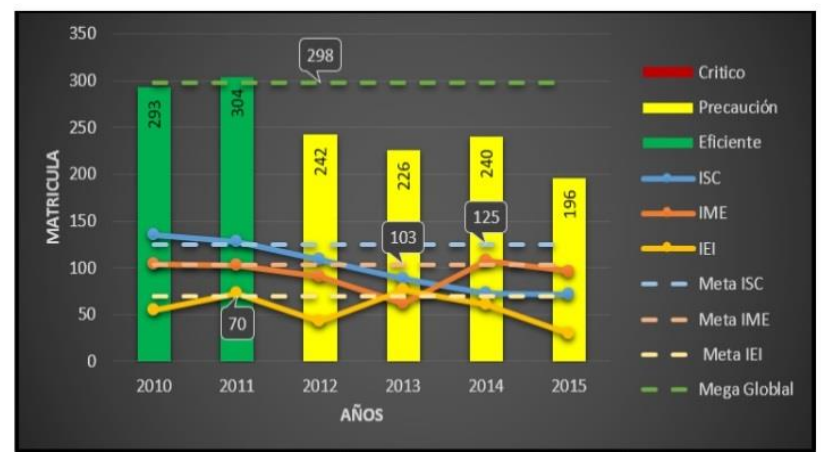

Fig. 4. Indicators of new entry, re-entry and total enrollment.

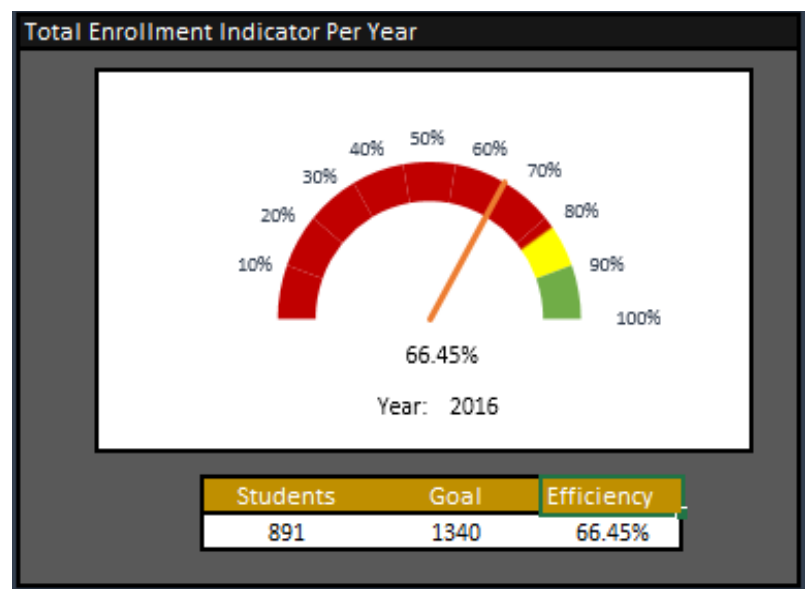

Fig. 5. KPI Total enrollment at 2016 year.

Finally, in the analysis carried out in 2015-2016 school year, the faculty absorbed 196 students, representing $65.77 \%$ with respect to the established goal, which is of 298 accepted students of new income.

In Fig. 5, the indicator obtained is in red, this dashboard was obtained from Power BI, this is a low level of acceptance of faculty for incoming and re-entry students. Design an action plan to help solve the problems that help increase the indicators, which may include marketing strategies, create new careers, and create mechanisms for evaluation and academic monitoring.

Because of the analysis of the information obtained there is a low level of student participation in research and technological development projects led by full-time teachers.

\section{CONCLUSION}

Once the maps were constructed and detailed, the strategic objectives are clearly defined, the selection of indicators is the natural continuation of the process, where the indicator is an element of objective measurement, which allows the establishment of goals over time; Goals that are quantifiable, ambitious, measurable, controllable and achievable; Which mark the milestones and desired rhythm of the evolution of the strategy in function of the current situation.

It should be noted that in the development of the BSC indicators now play an important role but in no case isolated and as an end, but always as a means directly related to the strategic objectives they measure; who in turn ere ordered in perspectives and related through cause-effect relationships within strategic maps.

The implementation of the BI solution allowed appreciate how the use of IT, and especially BI, can support the processes of management and decisions in contexts such as university education and contribute to strengthening initiatives aimed at improving decision-making process supported with the values obtained from the analyzed indicators.

The methodology used facilitated the identification of processes, activities and tasks of a BI solution. 


\section{REFERENCES}

[1] Cardona, S., The Business Intelligence and its application in some companies of the metropolitan area of Medellin.University EAFIT, 2005.

[2] Dresner, H., Profiles in Performance: Business Intelligence Journeys and the Roadmap for Change1989, U.S.A.: Wiley.

[3] Ekerson, W., Performance Dashboards: Measuring, Monitoring and Managing your Business.2010(Wiley ).

[4] Bustamante, A., et al., Soluciones de inteligencia de negocios en la práctica: apoyo a la toma de decisiones en proyectos educativos para población infantil vulnerable en el Caribe Colombiano. Revista de la Facultad de Ingenierías Fsicomecánicas, 2011. 10(2): p. 123-135.

[5] Blanco, F., Integrated management control.1976(Limusa).

[6] Meyer, J., Le controle de gestion1969, Paris, France: Presses Universitarires.

[7] Fernández, A. The Balanced Scorecard: Helping to Implement. 2001.

[8] Kaplan, R. and D. Norton, Translating Strategy into Action, The
Balanced Scorecard,1996, U.S.A.: Harvard Business School Press.

[9] Speckbacher, G., J. Bischof, and T. Pfeiffer., A descriptive analysis on the implementation of Balanced Scorecards in German-speaking countries. Management accounting research, 2003. 14(4): p. 361-370.

[10] Molleman, B., The challenge of implementing the Balanced Scorecard in 6th Twente Student Conference on IT, U.o. Twente, Editor 2007, Faculty of Electrical Engineering, Mathematics and Computer Science Enschede, The Netherlands.

[11] Kaplan, R. and D. Norton, The Balanced Scorecard,2009, Barcelona 2009: Gestion 2000, 2009.

[12] Klemenhagen, B., Applications Service Providers ASP. Vol. 1. 2000, USA: Cherry Tree.

[13] Microsoft. Introduction to Microsoft Power Query 2016 [cited 201612 Oct_2016]; Available from: https://support.office.com/eses/article/Introducción-a-Microsoft-Power-Query-para-Excel-.

[14] Microsoft. Power Pivot: data analysis and modeling for Excel. 2016 [cited 2016 12-Oct-2016]; Available from: https://support.office.com/eses/article/Power-Pivot-análisis-de-datos-eficaz-y-modelado-de-datos-enExcel-. 